\title{
Sport and exercise habits in children with juvenile idiopathic arthritis (JIA)
}

\author{
M Nørgaard ${ }^{1 *}$, T Herlin $^{2}$ \\ From 18th Pediatric Rheumatology European Society (PReS) Congress \\ Bruges, Belgium. 14-18 September 2011
}

\section{Background}

Over the last decade implementation of targeted therapy has improved the functional ability in JIA-children. Also, the attitude towards participation of JIA-children in sport has become less restrictive with growing evidence of the benefits of physical activity on e.g. disease, fitness and quality of life.

\section{Aim}

To explore the habits in gym classes and sport in 10-16 year-old JIA-children compared to gender- and agematched healthy controls.

\section{Methods}

68 JIA-children (females $60.3 \%)$, age $12.74( \pm 1.70)$ years, disease duration $5.72( \pm 4.17)$ years, and 118 healthy controls (females 50.8\%), age $12.36( \pm 1.74)$ years, answered questionnaires on sport and exercise habits and functional ability (CHAQ38). For JIA: VAS-pain, Patient- and Physician-GA were noted.

\section{Results}

Mean CHAQ38 scores for JIA: $0.1896( \pm 0.2025)$, controls: $0.0359( \pm 0.0799)$ indicated only minimal functional impairment in both groups. Pain assessments correlated well to CHAQ38 scores in JIA (p-values $<0.01$ ).

No significant differences were found between sportactive JIA-children and controls concerning type and number of sport activities or amount of time spent in sport. Significantly more JIA-children were not sportactive $(38 \%(26 / 68)$ vs. $25 \%(29 / 118))$, mainly due to joint pain $(12 / 26)$ and getting short of breath/sidestitches $(9 / 26)$.

\footnotetext{
* Correspondence: mettnoer@rm.dk

${ }^{1}$ Department of Physiotherapy, Aarhus University Hospital, Skejby, Denmark
} Full list of author information is available at the end of the article
Significantly fewer JIA-children participated fully in gym $(\mathrm{p}<0.01)$ and reported pain $(91 \%(62 / 68))$ and difficulties with certain activities $(\mathrm{p}<0.01)$. Strategies mainly used when pain; a short break (81\%), changing activity (58\%), continuing despite pain (37\%).

\section{Conclusion}

JIA-children still participate less in sport activities and are more challenged in gym classes than healthy peers, despite close-to-normal functional ability. However, sport-active JIA-children do not differ significantly from sport-active healthy peers.

\section{Author details}

${ }^{1}$ Department of Physiotherapy, Aarhus University Hospital, Skejby, Denmark. ${ }^{2}$ Department of Pediatrics, Aarhus University Hospital, Skejby, Denmark.

Published: 14 September 2011

doi:10.1186/1546-0096-9-S1-P126

Cite this article as: Nørgaard and Herlin: Sport and exercise habits in children with juvenile idiopathic arthritis (JIA). Pediatric Rheumatology 2011 9(Suppl 1):P126.

Submit your next manuscript to BioMed Central and take full advantage of:

- Convenient online submission

- Thorough peer review

- No space constraints or color figure charges

- Immediate publication on acceptance

- Inclusion in PubMed, CAS, Scopus and Google Scholar

- Research which is freely available for redistribution

Submit your manuscript at www.biomedcentral.com/submit

\section{() Biomed Central}

